\title{
Repression of the prolactin promoter: a functional consequence of the heterodimerization between Pit-1 and Pit-1 ß
}

\author{
R A Sporici, J S Hodskins, D M Locasto, L B Meszaros, A L Ferry, A M Weidner, \\ C A Rinehart', J C Bailey, I M Mains and S E Diamond
}

Department of Physiology, University of Kentucky College of Medicine, 800 Rose Street, Lexington, KY 40536, USA

${ }^{1}$ Department of Biology, Western Kentucky University, 1 Big Red Way, Bowling Green, KY 4210, USA

(Requests for offprints should be addressed to S E Diamond; Email: sediam0@uky.edu)

\begin{abstract}
The POU-homeodomain transcription factor Pit-1 is required for the differentiation of the anterior pituitary cells and the expression of their hormone products. Pit-1 $\beta$, an alternate splicing isoform, has diametrically different outcomes when it is expressed in different cell types. Pit-1 $\beta$ acts as a transcriptional repressor of prolactin (PRL) and growth hormone genes in pituitary cells, and as a transcriptional activator in non-pituitary cells. In order to explore these differences, we: (1) identified the transcriptional cofactors necessary for reconstitution of repression in non-pituitary cells; (2) tested the effect of the $\beta$-domain on heterodimerization with Pit-1 and physical interaction with the co-activator CREB binding protein (CBP); and (3) determined the $\beta$-domain sidechain chemistry requirements for repression. Co-expression of both Pit-1 isoforms reconstituted the repression of the PRL promoter in non-pituitary cells. The $\beta$-domain allowed heterodimerization with Pit-1 but blocked physical interaction with CBP, and specific chemical properties of the $\beta$-domain beyond hydrophobicity were dispensable. These data strongly suggest that Pit-1 $\beta$ represses hormone gene expression by heterodimerizing with Pit- 1 and interfering with the assembly of the Pit-1-CBP complex required for PRL promoter activity in pituitary cells.
\end{abstract}

Journal of Molecular Endocrinology (2005) 35, 317-331

\section{Introduction}

POU domain factors regulate transcription by interacting with themselves and with other proteins. The $33 \mathrm{kDa}$ POU-homeodomain transcription factor Pit-1 helps to establish anterior pituitary lactotroph, somatotroph, and thyrotroph lineages and proper expression of their respective hormone products: prolactin (PRL), growth hormone $(\mathrm{GH})$, and thyroid stimulating hormone subunit $\beta$ (TSH $\beta$ ). Pit-l's amino- (N-) amino acid (AA) terminal transactivation domain (TAD) activates transcription (Theill et al. 1989, Ingraham et al. 1990) and mediates dopamine repression (Lew \& Elsholtz 1995). Together, the POU-specific (AA 128-198) and POUhomeodomain (AA 214-273) form the carboxyl- (C-) terminal DNA binding and dimerization domain (DBD) (Bodner \& Karin 1987, Herr et al. 1988, Ingraham et al. 1988) (Fig. 1), which binds DNA with high affinity and specificity (Ingraham et al. 1990) and interacts with transcription cofactors (Xu et al. 1998).

Pit-1 transduces activation by the cyclic AMP (cAMP)-protein kinase A (PKA) pathway (Day et al. 1989, Keech \& Gutierrez-Hartmann 1989, Iverson et al. 1990, Conrad \& Gutierrez-Hartmann 1992, Keech et al. 1992) and by liganded estrogen receptor (Iverson et al. 1990). It also transduces the inhibition by dopamine and activin (Maurer 1981, Elsholtz et al. 1991, Sanyal \& Van 1997, Lacerte et al. 2004). In addition, Pit-1 can increase the acetylation state of the PRL promoter (Diamond \& Gutierrez-Hartmann 2000) and alter its chromatin structure (Kievit \& Maurer 2005). Pit-1 has been shown to interact with other DNA-binding proteins and coregulators that are incapable of independent DNA binding. For instance, recruitment of CREB binding protein $(\mathrm{CBP})$ by Pit-1 is required for PKA activation of the PRL promoter. Competition between the corepressor N-CoR and the coactivator CBP modulates the transcriptional activity of Pit-1 (Xu et al. 1998, Cohen et al. 1999, Zanger et al. 1999, Hashimoto et al. 2000, Scully et al. 2000, Zanger et al. 2001).

The $\beta$-isoform of Pit- 1 , Pit-1 $\beta$, differs only by the splice-insertion of the 26 amino acid $\beta$-domain at the beginning of exon 2 in the TAD (Fig. 1), yet it has diametrically opposite effects with regard to hormone gene expression in anterior pituitary cells. While Pit-1 enhances PRL and GH gene expression, Pit- $1 \beta$ blocks their gene expression and decreases the histone acetylation of their promoters in a manner dependent 


\section{DBD}

\section{TAD POU-Specific POU-Homeo}

\section{Transcriptional activation DNA binding, dimerization, Repression by dopamine chromatin alteration}
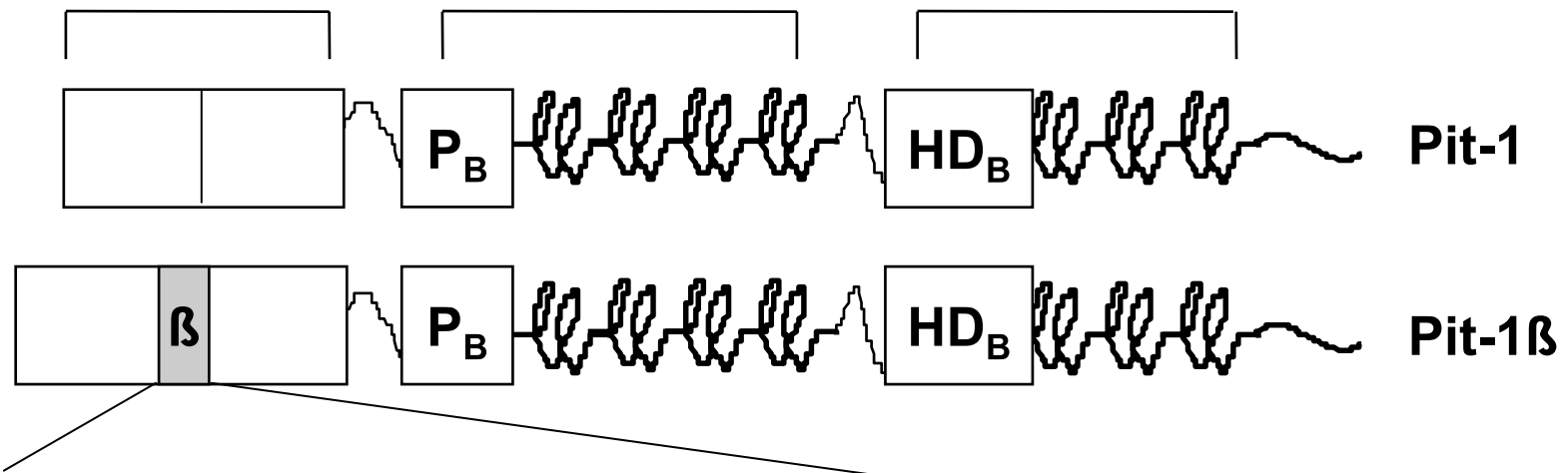

\section{VPSILS니QTPKCLHTYYFSMTTMGNT}

\section{Required for Repression}

Figure 1 The structure of Pit-1 and Pit-1 $\beta$. Upper, Pit-1, with its TAD, POU-specific, and POU-homeodomains. $P_{B}$, and $H D_{B}$ represent POU-specific and POU-homeodomain basic domains respectively; their $\alpha$-helices are represented graphically. Lower, Pit-1 $\beta$, with the location of the 26 amino acid $\beta$-domain and its sequence.

upon five hydrophobic $\beta$-domain residues (Fig. 1) (Diamond \& Gutierrez-Hartmann 1996, 2000, Ferry et al. 2005). Yet, in HeLa non-pituitary cells, Pit-1 $\beta$ activates hormone gene transcription. The reason for this cell-type specificity has remained unknown to date, but it seems that a difference between the pituitary and non-pituitary cell environments modulates Pit- $1 \beta$ transcriptional activity.

An important feature of POU factors is their ability to form cooperative homodimers and even heterodimers with other POU factors, both in the absence of DNA and even more so when bound to an appropriate DNA site. Consequently, diverse configurations of homodimeric and heterodimeric interactions emerge when different members of the POU domain gene family are coexpressed in the same cells or tissues. On some sites, Pit- 1 can bind as a heterodimer with the POU domain factor Oct-1, which results in synergistic transactivation of the PRL promoter. However, on most sites, Pit-1 appears to bind as a homodimer (Elsholtz et al. 1990, Ingraham et al. 1990, Voss et al. 1991, 1993). The specific domain of the POU domain (POU-S) is essential for Pit-1-Pit-1 interactions and the result is efficient transactivation. The importance of this homodimerization is underscored by the fact that dominant-negative
Pit-1 mutants, such as those that occur naturally in combined pituitary hormone deficiency (Arg271 Trp, Pro14 Leu and Pro24 Leu), impede the function of the wild-type Pit-1 transcribed from the other, wild type, allele. This phenomenon occurs despite their ability to bind DNA (Cohen et al. 1999, Parks et al. 1999, Pfaffle et al. 1999).

Similarly, Pit-1 $\beta$ blocks hormone gene expression even though it effectively binds DNA (Konzak \& Moore 1992, Morris et al. 1992, Theill et al. 1992). Some studies showed that the Pit-1 $\beta$ might induce repression in pituitary cells by altering the balance between competing coactivator and corepressor interaction with Pit-1 (Xu et al. 1998). We recently showed that Pit- $1 \beta$ reduces CBP recruitment to the PRL and GH promoters (Ferry et al. 2005). However, it is not clear whether the Pit-1 $\beta$ directly inhibits coactivator recruitment, or whether the repression is simply an effect of decreased Pit- 1 or Pit-1 $\beta$ availability due to heterodimerization. In order to distinguish between these possibilities, we tested the constraints for: (1) reconstitution of repression in nonpituitary cells; (2) the further constraints on repression added by CBP coactivator and PKA; (3) the effect of the $\beta$-domain on physical interaction with $\mathrm{CBP}$; and (4) $\beta$-domain sidechain chemistry. We demonstrate that the 
presence of Pit-1, CBP and PKA allow reconstitution of repression by Pit- $1 \beta$ in non-pituitary cells, and that the $\beta$-domain blocks physical interaction between Pit- 1 and a Pit-1-binding domain of CBP. In addition, we showed that specific chemical properties beyond hydrophobicity are dispensable. We propose a model in which Pit-1 $\beta$ heterodimerizes with Pit-1 and thus decreasing their efficiency as transcriptional activators. Furthermore, this heterodimerization may account for the limited access of Pit-1 to the CBP zinc fingers and therefore prevent the formation of the Pit-1-CBP complex required for PRL and GH promoter activity in pituitary cells.

\section{Materials and methods}

\section{Cell culture}

We maintained monolayer cultures of HeLa nonpituitary and GH3 rat pituitary tumor cells (Tashjian et al. 1968) in Dulbecco's Modified Eagle Medium (DMEM), 20\% fetal bovine serum (FBS) and $50 \mu \mathrm{g} / \mathrm{ml}$ penicillin and streptomycin, at $37^{\circ} \mathrm{C}$ in $5 \% \mathrm{CO}_{2}$ and changed the medium 16-18 h before each transfection. We harvested cells for transfection at approximately $80 \%$ confluence, using 0.05\% trypsin and $0.5 \mathrm{mM}$ EDTA.

\section{Plasmids}

Plasmid pA3 PRL luc, firefly luciferase driven by the proximal (-425) rat (r) PRL promoter, was described previously (Conrad \& Gutierrez-Hartmann 1992, Diamond \& Gutierrez-Hartmann 1996, 2000, Diamond et al. 1999). Plasmids pRSV HA Pit-1, pRSV HA Pit-1 $\beta$, pRSV PKA $\beta$ and pRSV $\beta$-globin, respectively driven by the RSV promoter, were described previously (Diamond \& Gutierrez-Hartmann 1996, 2000, Diamond et al. 1999). Plasmid RSV CBP was the generous gift of Dr Chee-Gun Lee. Plasmid pCMX NCoR was the generous gift of Dr Kate Horwitz. Plasmid pGEX-Pit-1 was the generous gift of Dr Gutierrez-Hartmann.

Mutant Pit-1 $\beta$ constructs in mammalian expression vectors were constructed by nested PCR mutagenesis of the Pit-1 transactivation domain as described previously (Diamond \& Gutierrez-Hartmann 1996, 2000). The pRSV HA Pit-1 plasmid was used as a substrate for PCR mutagenesis, in which the 26 amino acid $\beta$-domain was substituted with altered sequences, and a HA epitope tag was retained at the amino terminus of all of the Pit-1 constructs. Amplified DNA was initially subcloned into pCR 2.1 (Invitrogen, Carlsbad, CA, USA), and the presence of each introduced mutation and the integrity of its TAD region verified by dideoxy sequencing. HA-tagged Pit-1 TAD sequences were then excised from pCR2.1 by digestion with HinD III and PpuM I and were ligated to the unique HinD III and PpuM I sites of pRSV-Pit-1.
Expression vectors for labeled Pit- 1 and Pit- $1 \beta$, T7 Pit-1 and T7 Pit-1 $\beta$, were constructed by PGR amplification of full length rat Pit- 1 and Pit- $1 \beta$, followed by ligation to pCR4 Blunt TOPO (Invitrogen). The GST-fusion expression vector CBP AA 312-440 was constructed by PCR amplification of mouse CBP nucleotides 936-1320 with primers encoding BamH I and Sma I sites, followed by ligation to pCR4 Blunt TOPO. The CBP insert was then subcloned to the unique BamH I and Sma I sites of pGEX 4T-1.

\section{Transfection}

We introduced DNA into GH3 pituitary or HeLa non-pituitary cells by electroporation as follows. Approximately $2-3 \times 10^{6}$ enzymatically dispersed cells were mixed with plasmid DNA in a sterile gene-pulse chamber and exposed to a controlled electrical field of $525 \mu$ Farads at $220 \mathrm{~V}$, as described previously (Diamond \& Gutierrez-Hartmann 1996, Ferry et al. 2005). We performed transient transfections in triplicate in at least three separate experiments. Cells from individual transfections then were maintained in DMEM, 20\% FBS, $50 \mu \mathrm{g} / \mathrm{ml}$ penicillin and streptomycin, at $37^{\circ} \mathrm{C}$ in $5 \% \mathrm{CO}_{2}$.

A 1:3 Pit-1:Pit-1 $\beta$ plasmid DNA ratio that results in equal levels of protein expression was used (Diamond \& Gutierrez-Hartmann 1996, 2000, Diamond et al. 1999). We controlled the nonspecific effect of the RSV promoters upon transcription factor availability by including amounts of pRSV $\beta$-globin plasmid DNA in all assays to render the total pRSV DNA concentration constant. Plasmid pRLG Renilla (15 ng) was included as an internal control for all transfections.

\section{Luciferase assays}

After incubation for $24 \mathrm{~h}$, cells were harvested and assayed using the Dual Luciferase Reporter Assay System (Promega) and a Monolight 3010 Luminometer (Analytical Luminescence Laboratories, San Diego, CA, USA). Firefly luciferase light units for each transfection were normalized for Renilla luciferase light units. We expressed results as mean fold activation of the PRL promoter \pm S.E.M. and used Fisher's protected test of least significant differences to calculate the significance of differences between multiple conditions. In determining the ratios of two independent variables, the relative errors were added in quadrature to determine the S.E.M. of the ratio.

\section{Western Blot analysis of HA-tagged Pit-1 proteins}

Transient transfections were performed as above. Three aliquots of cells were pooled and harvested with PBS containing $3 \mathrm{mM}$ EDTA, pelleted and resuspended in 
2X Laemmli sample buffer, and passed through a $25 \mathrm{G}$ needle seven times. Equal volumes of each extract were separated on $15 \%$ SDS polyacrylamide gels and transferred to Immobilon-P PVDF membrane (Millipore, Bedford, MA, USA). The HA-tagged Pit- 1 proteins were detected with a mouse monoclonal anti-HA HRPconjugated antibody (Roche Diagnostics, Indianapolis, IN, USA) and ECL Advance media (Amersham Biosciences, Piscataway, NJ, USA). Dilutions of 1:1000 of the anti-HA monoclonal antibody were used.

\section{GST fusion protein synthesis}

Recombinant fusion proteins GST only, GST-Pit-1, and GST-CBP AA 312-440 were prepared from bacterial extracts (Bradford et al. 1995, 2000). Overnight cultures of Escherichia Coli BL-21 (DE3) pLysS (Stratagene, La Jolla, CA, USA), transformed with plasmids pGEX 4T-1, pGEX Pit-1, or pGEX CBP 312-440 were diluted 1:10 in fresh Luria broth supplemented with ampicillin $(50 \mu \mathrm{g} / \mathrm{ml})$ and grown at $30^{\circ} \mathrm{C}$ to an optical density at $600 \mathrm{~nm}$ of $0 \cdot 4$. Cultures were induced by addition of $1 \mathrm{mM}$ isopropyl- $\beta$-D-thiogalactopyranoside for $2 \mathrm{~h}$ at $30^{\circ} \mathrm{C}$. Bacterial cells were harvested by centrifugation and resuspended and lysed in 1/10 volume of B-Per (Promega, Madison, WI, USA), with the recommended concentration of complete protease inhibitor cocktail (Roche Molecular Biochemicals, Indianapolis, IN, USA). Cellular debris was removed by centrifugation. Supernatants were bound to glutathione-sepharose (Amersham-Pharmacia, Piscataway, NJ, USA) for $1 \mathrm{~h}$ at room temperature and washed extensively in PBS supplemented with protease inhibitors. Bound protein was analyzed by sodium dodecyl sulfate (SDS)polyacrylamide gel electrophoresis and western blot with antibodies against GST. Protein concentration was measured by the Bradford assay (Bradford 1976).

\section{In vitro protein interaction assays}

Flourotect-Green (Promega, Madison, WI, USA) lysinelabeled Pit- 1 and Pit- $1 \beta$ proteins were synthesized in vitro with the TNT coupled transcription-translation reticulocyte lysate system (Promega), according to the manufacturer's protocol. Equal amounts $(2 \mu \mathrm{g})$ of GST fusion proteins were bound to glutathione-agarose beads and suspended in binding buffer $(40 \mathrm{mM}$ HEPES, $100 \mathrm{mM}$ $\mathrm{NaCl}, 5 \mathrm{mM} \mathrm{MgCl} 2,0.5 \mathrm{mM}$ EDTA, $0.5 \mathrm{mM}$ PMSF, $0.05 \%$ Nonidet P-40, $1 \mathrm{mM}$ dithiothreitol, $\mathrm{pH} 7 \cdot 5$ ) supplemented with protease inhibitors. In vitro-translated and labeled protein was incubated with immobilized GST, GST-Pit-1, or GST-CBP AA 312-440 in a final volume of $0.5 \mathrm{ml}$ binding buffer containing $50 \mu \mathrm{g} / \mathrm{ml}$ ethidium bromide and mixed by rocking for $1 \mathrm{~h}$ at room temperature. Beads were collected by a rapid, $30 \mathrm{~s}$ centrifugation at $1000 \mathrm{~g}$, and then washed five times for
5 min each in $0.5 \mathrm{ml}$ binding buffer containing $0.1 \%$ Triton X-100. Bound labeled proteins were eluted by heating to $80{ }^{\circ} \mathrm{C}$ in SDS sample buffer and analyzed by SDS-polyacrylamide gel electrophoresis and autoradiography (Bradford et al. 1995, 2000). Bands were quantitated using a Molecular Dynamics Typhoon laser-scanning densitometer with Imagequant software (Amersham Biosciences, NJ, USA).

\section{Statistics}

The data were analyzed using GraphPad Prism software (San Diego, CA, USA). Differences between groups were considered significant for $P$ value $<0.05$ as analyzed by Fishers least significant differences multiple comparison procedure.

\section{Results}

\section{Reconstitution of pituitary-specific repression in non-pituitary cells}

Pit-1 and Pit-1 $\beta$ have a very limited expression pattern and are mainly found in the anterior pituitary gland. Our previous studies showed that Pit-1 $\beta$ functioned as a repressor of the PRL promoter only in pituitary cells (Diamond \& Gutierrez-Hartmann 1996, 2000, Diamond et al. 1999, Ferry et al. 2005). We speculated that this pituitary-specific repression might be the result of the heterodimerization between Pit-1 and Pit- $1 \beta$. To test this hypothesis, we measured the effect of increasing doses of Pit-1 $\beta$ on activation of the proximal PRL promoter in HeLa non-pituitary cells in the presence of Pit-1. When transfected alone, both Pit- 1 and Pit-1 $\beta$ significantly increased PRL promoter activity by 12 -fold over the vector only control (Fig. 2) Combination of equal amounts $(10 \mu \mathrm{g})$ of each isoform resulted in a significant drop in the PRL promoter activity compared with each isoform alone. However, increasing the amount of Pit-1 $\beta$ to 15, 20, 25 and $30 \mu \mathrm{g}$ increased PRL promoter activity by 20-fold, 27-fold, 80 -fold and 100 -fold respectively. These results suggest that repression by the $\beta$-domain requires the presence of both isoforms and that the interaction or heterodimerization between Pit-1 and Pit-1 $\beta$ leads to decreased intracellular availability and consequently to reduced efficiency as transcriptional activators in HeLa cells.

We previously found that repression by Pit- $1 \beta$ in pituitary cells is limited to promoters that rely on Pit- 1 to recruit CBP (Ferry et al. 2005). Pituitary cells express an abundance of $\mathrm{CBP}$ relative to many non-pituitary cells (Xu et al. 1998), providing a possible mechanism for repression. We therefore investigated the effect of the putative heterodimerization between Pit- 1 and Pit- $1 \beta$ on the activation of PRL promoter in the presence of CBP in HeLa non-pituitary cells. As shown in Fig. 3, there 


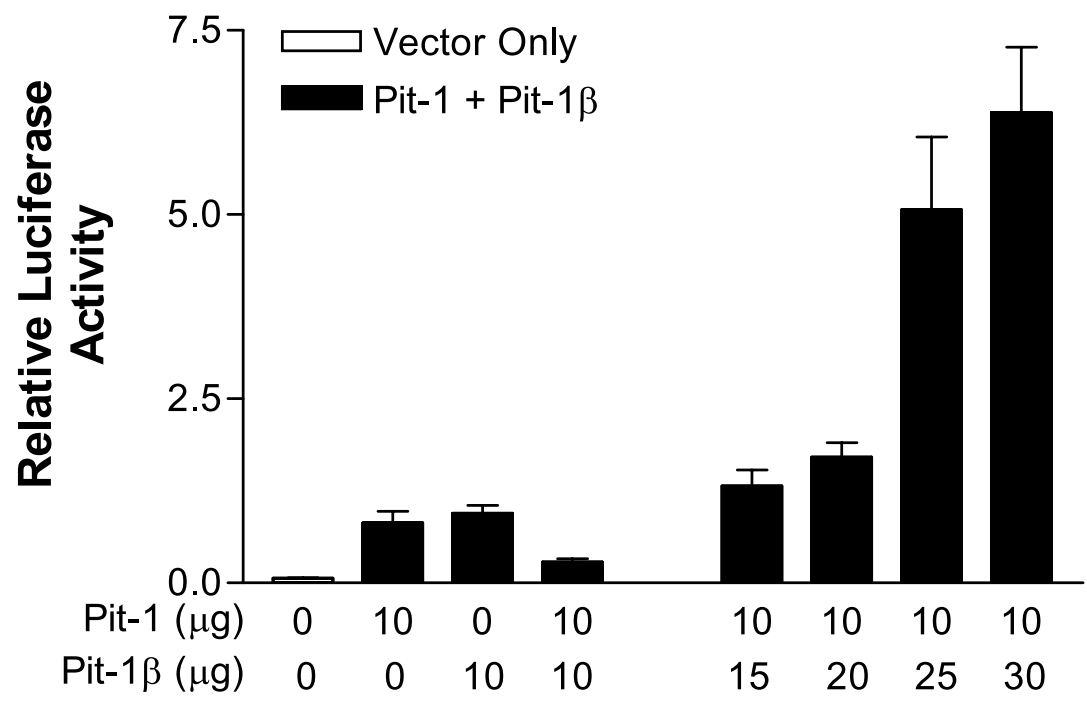

Figure 2 Effects of Pit-1 $\beta$ on activation of the $r P R L$ promoter in HeLa non-pituitary cells in the presence of Pit-1. Plasmid pA3 PRL luc-425 $(3 \mu \mathrm{g})$ and pRSV HA Pit-1 $(10 \mu \mathrm{g})$, together with $0-30 \mu \mathrm{g}$ RSV HAPit-1 $\beta$ were introduced into HeLa non-pituitary cells by electroporation. Total RSV promoter amounts were maintained constant with pRSV $\beta$-globin DNA. After $24 \mathrm{~h}$, cells were harvested, and total light units were measured (See Materials and methods).

was no effect on PRL promoter activity when HeLa cells were transfected with CBP alone. Addition of $10 \mu \mathrm{g}$ of either Pit-1 $\beta$ or Pit-1 significantly increased PRL promoter activity 9-fold compared with vector only. Again, the further addition of increasing amounts of 15 ,
20, 25, and $30 \mu \mathrm{g}$ Pit-1 $\beta$ resulted in augmented PRL promoter activity by $12,19,25,33$-fold respectively. Interestingly, addition of equal inputs of Pit- 1 and Pit- $1 \beta$ did not repress PRL promoter activity in the presence of CBP. It is possible that CBP binds Pit-1 before Pit-1 $\beta$

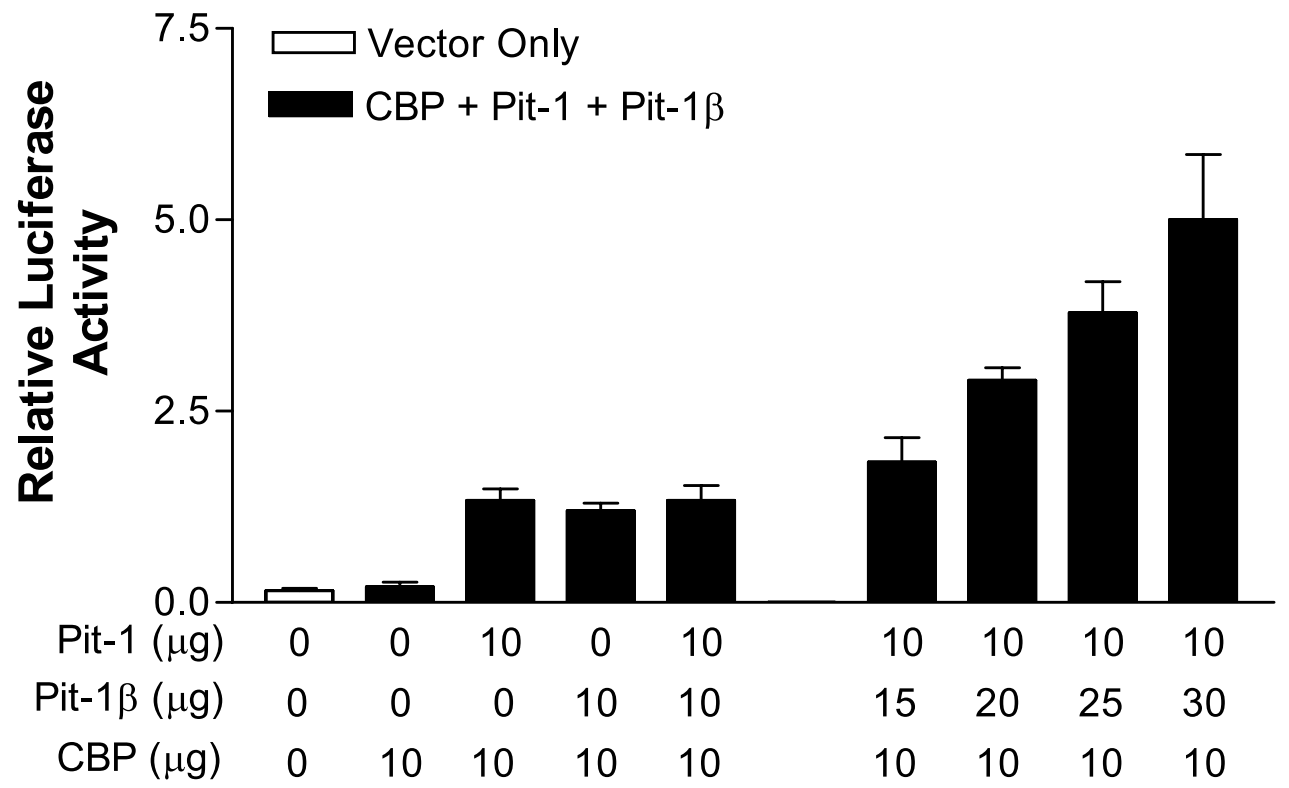

Figure 3 Effects of Pit-1 $\beta$ on activation of the rPRL promoter in HeLa non-pituitary cells in the presence of Pit-1 and CBP. Plasmid pA3 PRL luc-425 $(3 \mu \mathrm{g})$, pRSV HA Pit-1 $(10 \mu \mathrm{g})$ and pRSV CBP $(10 \mu \mathrm{g})$, together with $0-30 \mu \mathrm{g}$ RSV HAPit-1 $\beta$ were introduced into HeLa non-pituitary cells by electroporation. Total RSV promoter amounts were maintained constant with pRSV $\beta$-globin DNA. After $24 \mathrm{~h}$, cells were harvested, and total light units were measured (See Materials and methods). 


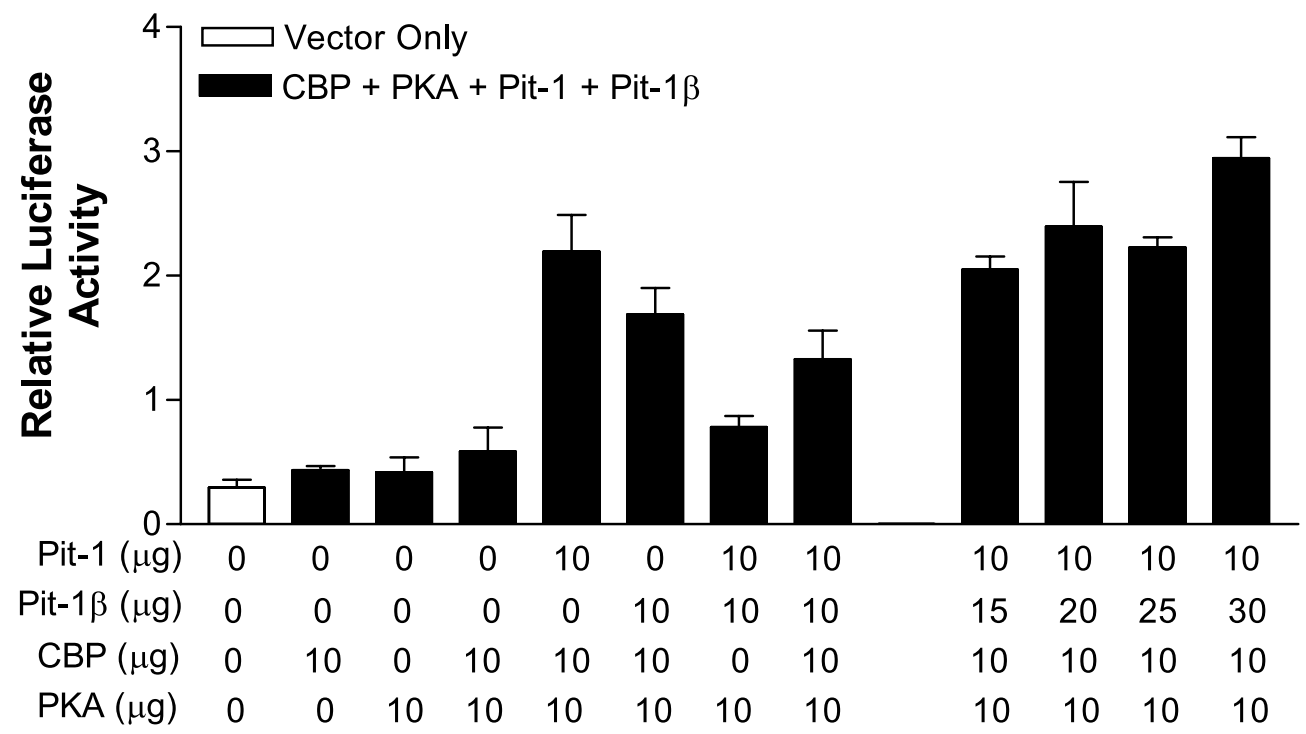

Figure 4 Effects of Pit-1 $\beta$ on activation of the rPRL promoter in HeLa non-pituitary cells in the presence of Pit-1, PKA $\beta$ and CBP. Plasmid pA3 PRL luc-425, $(3 \mu \mathrm{g}), \mathrm{pRSV}$ HA Pit-1 $(10 \mu \mathrm{g}), \mathrm{pRSV}$ CBP $(10 \mu \mathrm{g})$ and pRSV PKA $\beta(10 \mu \mathrm{g})$ together with 0-30 $\mu \mathrm{g}$ RSV HAPit-1 $\beta$, were introduced into HeLa non-pituitary cells by electroporation. Total RSV promoter amounts were maintained constant with pRSV $\beta$-globin DNA. After $24 \mathrm{~h}$, cells were harvested, and total light units were measured (See Materials and methods).

does and thus prevents the heterodimerization between Pit- 1 and Pit-1 $\beta$. As well, interactions between all three players may take place simultaneously and produce a sufficient amount of Pit-1-CBP complex to activate the PRL promoter.

It has been shown that POU factors can be modified by phosphorylation (Kapiloff et al. 1991, Segil et al. 1991). Anterior pituitary PRL gene expression is high in lactotrophs, due to the tonic activity of the cAMPsignaling cascade (Pickett \& Gutierrez-Hartmann 1997). This signal is transduced to the PRL promoter through CBP and Pit-1 (Xu et al. 1998, Zanger et al. 1999). This left the possibility that heterodimerization between Pit-1 and Pit- $1 \beta$ blocks PKA-activation of the PRL promoter through Pit-1 and CBP. To test this hypothesis, we introduced Pit-1 $\beta$ into HeLa non-pituitary cells with Pit-1, CBP, and PKA's catalytic subunit, PKA $\beta$ (Fig. 4). Either Pit-1 or Pit-1 $\beta$ in combination with $\mathrm{CBP}$ and PKA $\beta$ activated the PRL promoter approximately 7 -fold compared with the vector only control. Addition of both isoforms in combination with $\mathrm{CBP}$ and PKA $\beta$ resulted in a significant drop in the PRL promoter activity. However, addition of $15,20,25$, and $30 \mu \mathrm{g}$ Pit- $1 \beta$ increased PRL promoter activity in a dose-dependent manner between 7 and 10 -fold. Pit-1 $\beta$ repression was more pronounced in the absence of CBP. Interestingly, activation of the PKC signaling pathway also allows reconstitution of repression by Pit- $1 \beta$ in the presence of Pit- 1 and CBP, while expression of N-CoR does not allow reconstitution of repression in the presence of any combination of Pit-1 $\beta$, Pit-1 and CBP (data not shown). These experiments reconstitute, for the first time, repression by Pit- $1 \beta$ in non-pituitary cells, and they indicate that the $\beta$-domain blocks the ability of Pit- 1 and CBP to transduce cAMP/PKA activation of the PRL promoter.

\section{The $\beta$-domain blocks physical interaction between Pit-1 and CBP}

We next sought to address the question whether Pit-1 $\beta$ might repress PRL promoter activity by blocking Pit-1 dimerization itself, or by blocking a downstream action of Pit-1 dimers such as recruitment of phosphorylated GBP. In order to test this possibility, we examined the ability of Pit- 1 vs Pit- $1 \beta$ to physically interact with Pit- 1 and CBP in vitro through a GST pull-down assay. We chose the region of CBP containing AA 312-440 because it contains a CBP zinc-finger domain sufficient to bind Pit-1 in vitro, and functionally interact with Pit-1 in vivo (Tolon et al. 1998, Zanger et al. 1999).

Fusion proteins containing GST-linked Pit- 1 and CBP AA 312-440 were constructed, immobilized on glutathione agarose, and used in pull-down assays with fluorescently labeled Pit-1 or Pit-1 $\beta$ (see Materials and methods). Incubations were performed with equivalent amounts of beads, bound GST protein, bound GSTPit-1 fusion protein, and bound GST-CBP AA 312-440 fusion protein in the presence of ethidium bromide to block nonspecific protein-DNA interactions (Lai \& Herr 1992, Bradford et al. 2000). As shown in a representative 
A.

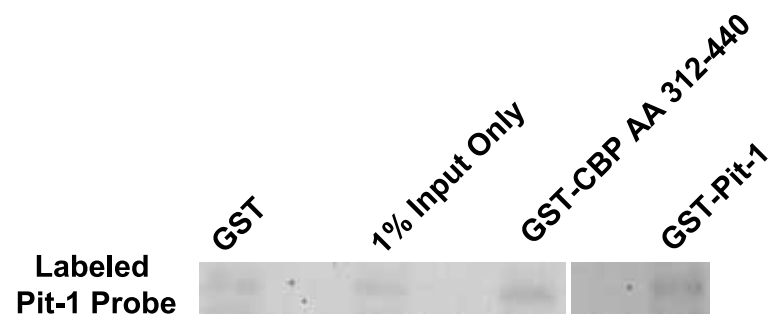

Labeled

Pit-1 $\beta$ Probe

B.

\section{Labeled Pit-1 $(\beta)$ Protein Bound}

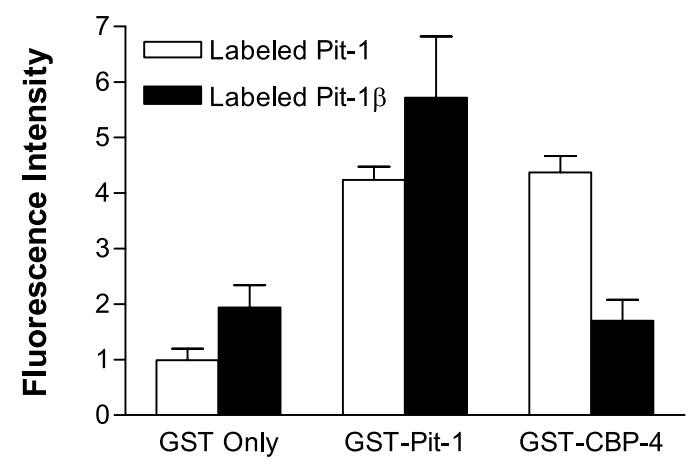

Figure 5 Effects of The $\beta$-domain on physical interaction between Pit-1 and select CBP domains in vitro. Aliquots $(50 \mu \mathrm{l}$ packed volume) of glutathione-Sepharose beads, bound to 2 ug of GST (lane 1), 1\% of labeled Pit-1 protein input (lane 2), GST-CBP AA 312-440 (lane 3), or GST-Pit-1 (lane 5) were incubated with equal amounts of in vitro-transcribed and translated labeled Pit-1 (upper panel) or Pit-1 $\beta$ (lower panel). A representative SDS PAGE gel is shown (A), and the results of seven pull-down experiments are quantified (B).

experiment in Figure 5A, and quantified from seven such experiments in Figure 5B, Pit-1 bound both GST-Pit-1 and GST-CBP AA 312-440 at levels 4-fold above background, while Pit-1 $\beta$ bound GST-Pit-1 at levels nearly 3 -fold above background but failed to bind GST-CBP AA 312-440 at levels significantly above background. These results provide physical evidence that Pit-1 $\beta$ interacts with Pit-1 but not with the AA 312-440 binding region of CBP, and that the $\beta$-domain presence may render the heterodimer incapable of interacting

\section{The sidechain length of hydrophobic residues is not necessary for repression}

In order to address how the $\beta$-domain insertion might affect Pit-1-CBP interaction, we analyzed the $\beta$-domain sequence constraints on repression. Changes in AA sidechain length can eliminate binding between polypeptides by steric interference or by removing interacting sidechain elements from the same vicinity $(\mathrm{Vu}$ et al. 2001). In order to test the constraints on $\beta$-domain sidechain length, we substituted the five residues previously shown to be required for repression (Leucine 7, Isoleucine 8, Tyrosine 17, Phenylalanine 18 and Methionine 20) with AAs of similar chemistry but different sidechain length (Fig. 6). For Leucine 7 and Isoleucine 8, we substituted Valine and Methionine; for Tyrosine 17, we substituted Tryptophan and Phenylalanine; for Phenylalanine 18, we substituted Tryptophan and Tyrosine; for Methionine 20, we substituted Valine and Isoleucine.

To ensure that mutagenesis did not eliminate transcription function, we tested the mutant Pit-1 $1 \beta \mathrm{s}$ in isoform-insensitive HeLa non-pituitary cells (Diamond \& Gutierrez-Hartmann 1996) in the presence of the rPRL promoter-driven luciferase reporter pA3-425 PRL luc, which contains sequences sufficient to confer celltype specific gene expression in transient transfection experiments (Fig. 6A) (Camper et al. 1985, GutierrezHartmann et al. 1987, Elsholtz et al. 1991) (See Materials and methods). Pit-1 $\beta$ increased transcription of the PRL promoter 17 -fold compared with the vector-only control, as seen previously (Diamond \& GutierrezHartmann 1996, Ferry et al. 2005). All of the sidechain length substitution mutants increased PRL promoter activity (from 3- to 21-fold). The variation in transcriptional potency in these experiments was similar to that among single amino acid substitutions in our previous substitution mutagenesis of the $\beta$-domain (Diamond \& Gutierrez-Hartmann 2000), and most of the mutants had similar transcription potency to wild-type Pit-1 $\beta$.

In order to determine the tolerance of repression for these alterations in sidechain-length, we introduced wild type and mutant Pit-1 $\beta$ s into GH3 pituitary cells by electroporation with pA3 -425 PRL luc (See Materials and methods) (Fig. 6B). Pit- $1 \beta$ reduced PRL promoter activity by $60 \%$ compared with the vector only control, and all of the sidechain-length mutants repressed PRL promoter activity by $41-85 \%$. These data demonstrate that the sidechain lengths of these hydrophobic $\beta$-domain residues are not necessary for repression.

\section{The aliphatic/aromatic character of hydrophobic residues is not necessary for repression}

Hydrophobic amino acids fall into two broad categories with different structures and chemical properties: aliphatic vs aromatic. Aliphatic sidechains are unsubstituted hydrocarbon chains subject to nucleophilic substitution, while aromatic sidechains incorporate closed planar rings and are subject to electrophilic 
A.

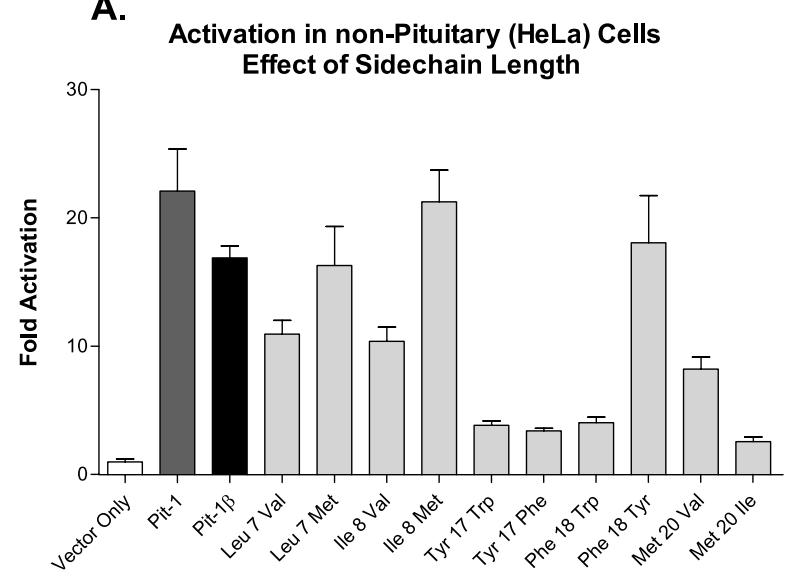

B.

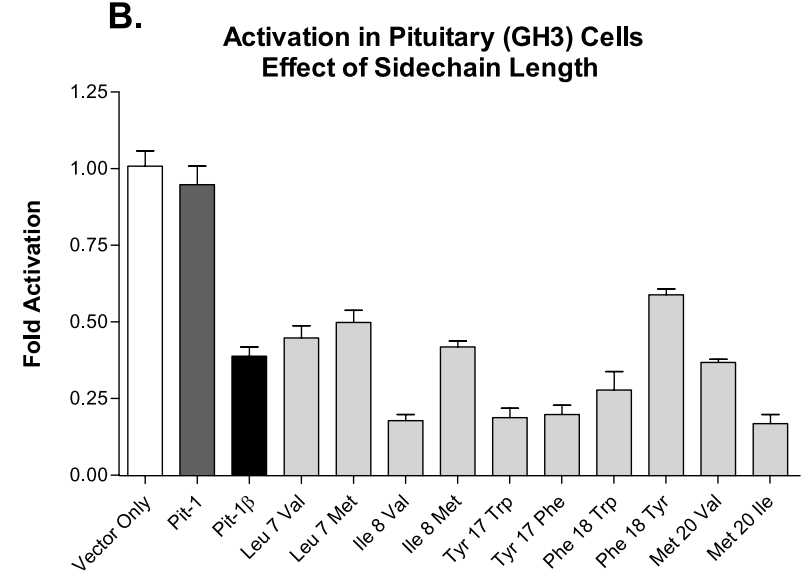

Figure 6 Sidechain length mutations. Effects of Pit- $1 \beta$ constructs on activation of the $\mathrm{PPRL}$ promoter in non-pituitary HeLa cells $(A)$ and GH3 pituitary cells (B). Plasmid pA3 PRL luc-425 $(3 \mu \mathrm{g})$, together with wild type or mutant pRSV HA Pit-1 $\beta(30 \mu \mathrm{g})$, were introduced into $\mathrm{GH} 3$ pituitary cells by electroporation. Total RSV promoter amounts were maintained constant with pRSV $\beta$-globin DNA. After $24 \mathrm{~h}$, cells were harvested, and total light units were measured (See Materials and methods).

substitution. These differences affect protein conformation and intermolecular interactions with ligands and other proteins (Heyl et al. 1994, Deardorff \& Sachs 1997, Murray et al. 1998, Nakagawa et al. 2000).

For the aliphatic residues Leucine 7, Isoleucine 8, and Methionine 20, we substituted the aromatic residues Tyrosine and Phenylalanine. For the aromatic residues Tyrosine 17 and Phenylalanine 18, we substituted the aliphatic residues Leucine and Isoleucine. In addition, we constructed two multiple substitution constructs, where multiple hydrophobic residues were similarly substituted: 4 substitutions (Leu 7 Tyr, Ile 8 Phe, Tyr 17 Leu, Phe 18 Ile) and 5 substitutions (Leu 7 Tyr, Ile 8 Phe, Tyr 17 Leu, Phe 18 Ile, Met 20 Phe).

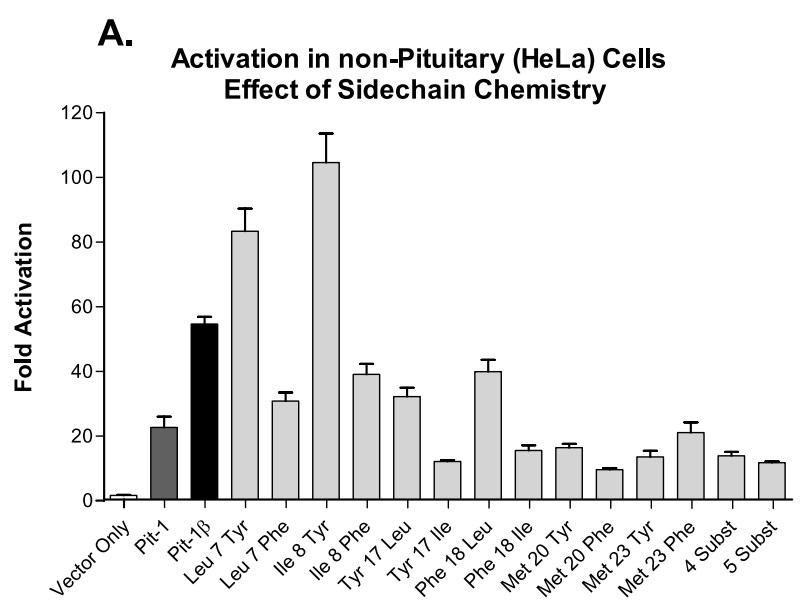

B.

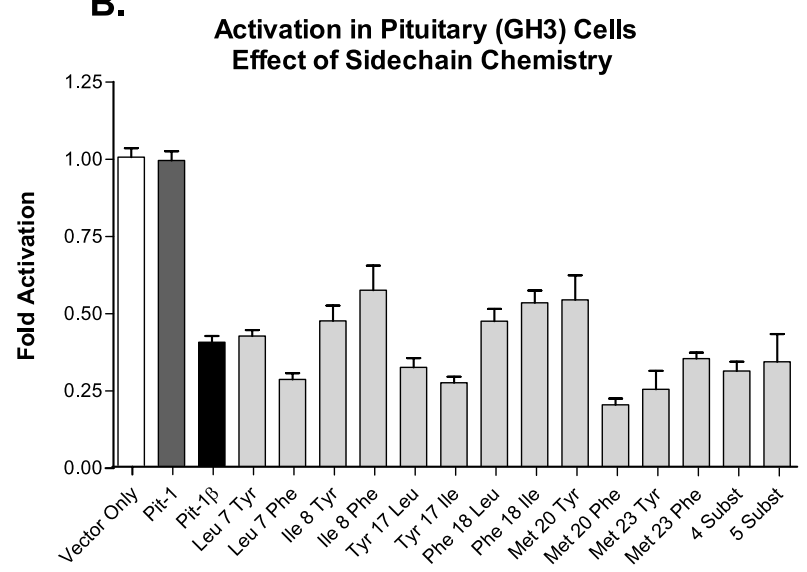

Figure 7 Aliphatic vs aromatic mutations. Effects of Pit-1 $\beta$ constructs on activation of the rPRL promoter in non-pituitary HeLa cells $(A)$ and $\mathrm{GH} 3$ pituitary cells $(B)$. Plasmid pA3 PRL luc-425 $(3 \mu \mathrm{g})$, together with wild type or mutant pRSV HA Pit-1 $\beta(30 \mu \mathrm{g})$, were introduced into GH3 pituitary cells by electroporation. Total RSV promoter amounts were maintained constant with pRSV $\beta$-globin DNA. After $24 \mathrm{~h}$, cells were harvested, and total light units were measured (See Materials and methods).

When expressed alone in HeLa non-pituitary cells (Fig. 7A), the sidechain-length substitution mutants increased $\mathrm{rPRL}$ promoter activity compared with the vector-only control from 9 - to 104 -fold versus 54 -fold for Pit-1 $\beta$. The differences in transcriptional potency in these experiments were smaller than those in our previous substitution mutagenesis of the $\beta$-domain (Diamond \& Gutierrez-Hartmann 2000), but most of the mutants had a somewhat reduced transcription potency compared with wild-type Pit-1 $\beta$. Of note, the four- and five-substitution mutants were among the least transcriptionally active of the constructs. This is reminiscent of the more severe effects on transcription potency among larger epitope substitutions (Diamond \& Gutierrez-Hartmann 2000). 
Table 1 Random $\beta$-domains

\begin{tabular}{ll} 
& $\boldsymbol{\beta}$-domain sequence \\
\cline { 2 - 2 } Wild type & VPSILSLIQTPKCLHTYFSMTTMGNT \\
RAN 1 & YVLCTPSQFIMTGTLPSTSIMTNHKL \\
RAN 2 & MKVSCTSSMYPLGTPNTIITFTLQLH \\
RAN 3 & PGFTLQTMLSVSTISPINTCHLMTYK
\end{tabular}

These data demonstrate that the $\beta$-domain mutants retain transcriptional potency.

In GH3 pituitary cells, the sidechain-length mutants repressed rPRL promoter activity by $46 \%$ to $75 \%$ (Fig. 7B) compared with the vector-only control. Surprisingly, the $\beta$-domain tolerated substitution of four or five hydrophobic residues. These data demonstrate that the aliphatic vs aromatic chemistry of Leucine 7 , Isoleucine 8, Tyrosine 17 , Phenylalanine 18, and Methionine 20 is not required for repression.

\section{$\beta$-domain amino acid order is not required for repression}

The lack of constraint on sidechain chemistry for these five hydrophobic amino acids suggested that the $\beta$-domain might function solely through its hydrophobicity. A prediction of such a model would be that sequence order would not be necessary for repression, so long as hydrophobicity was preserved. We used a random number generator to scramble the $\beta$-domain sequence in three different ways. We then substituted a scrambled domain for the wild-type $\beta$-domain in mutant constructs (Table 1).

All of the scrambled Pit- $1 \beta$ proteins retained basal transcriptional potency in the isoform-insensitive HeLa reconstitution assay (Fig. 8A). They increased PRL promoter activity 7- to 15-fold compared with the vector-only control, vs 18 -fold for wild-type Pit-1 $\beta$. In GH3 pituitary cells, the scrambled $\beta$-domain-containing proteins reduced PRL promoter activity (Fig. 8B) between 69 and $77 \%$ compared with the vector only control. These data demonstrate that $\beta$-domain amino acid order is not required for repression.

\section{Hydrophobic sidechains are required for repression}

If the $\beta$-domain functions solely through its hydrophobicity, other hydrophobic $\beta$-domain sidechains should be required for repression. We sequentially substituted alanines for five untested hydrophobic $\beta$-domain residues - valine 1 , isoleucine 4 , leucine 5 , leucine 14 , and methionine 23. Alanine substitution has been used in several systems to probe structure and function by eliminating most sidechain chemistry (Wertman et al. 1992, Diamond \& Gutierrez-Hartmann 2000) reviewed
A.

\section{Activation in non-Pituitary (HeLa) Cells Effect of Amino Acid Order}

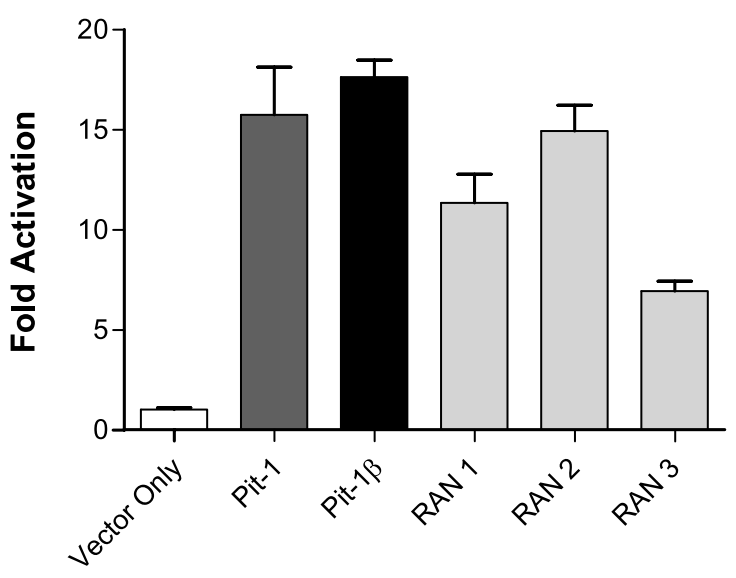

B.

\section{Activation in Pituitary (GH3) Cells Effect of Amino Acid Order}

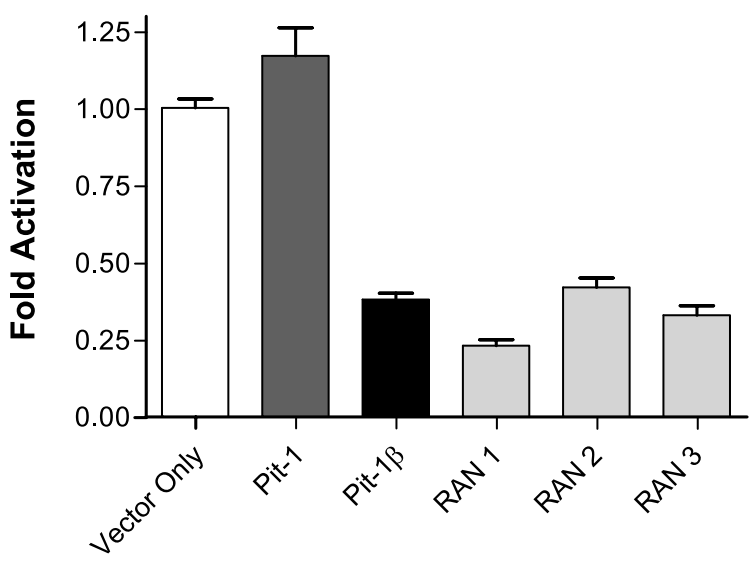

Figure 8 Random $\beta$-domains. Effects of Pit- $1 \beta$ constructs on activation of the $\mathrm{rPRL}$ promoter in non-pituitary HeLa cells $(A)$ and GH3 pituitary cells (B). Plasmid pA3 PRL luc-425 $(3 \mu \mathrm{g})$, together with wild type or mutant pRSV HA Pit-1 $\beta(30 \mu \mathrm{g})$, were introduced into $\mathrm{GH} 3$ pituitary cells by electroporation. Total RSV promoter amounts were maintained constant with pRSV $\beta$-globin DNA. After $24 \mathrm{~h}$, cells were harvested, and total light units were measured (See Materials and methods).

earlier by Diamond \& Kirkegaard 1994. Alanine is common (Klapper 1977), uncharged, and has minimal effects on protein secondary structure. While routinely categorized as hydrophobic because of its aliphatic methyl sidechain, it is actually no more hydrophobic 
A.

\section{Activation in non-Pituitary (HeLa) Cells Effect of Hydrophobic Sidechains}

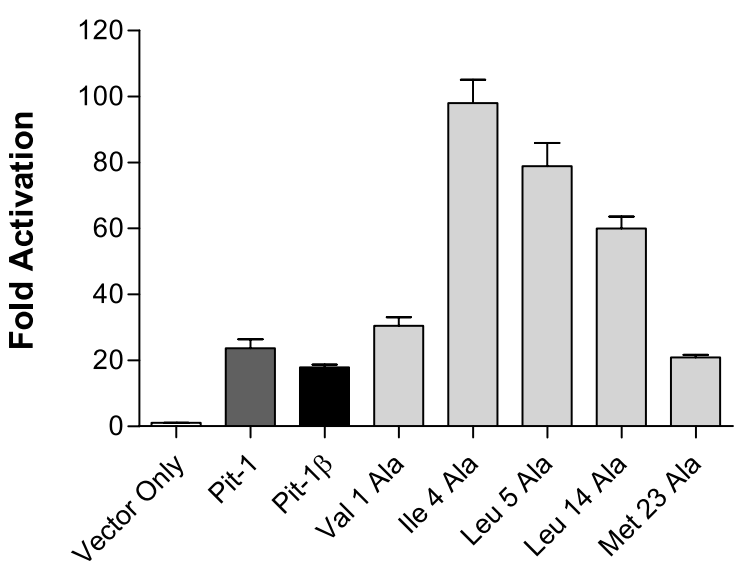

B.

\section{Activation in Pituitary (GH3) Cells Effect of Hydrophobic Sidechains}

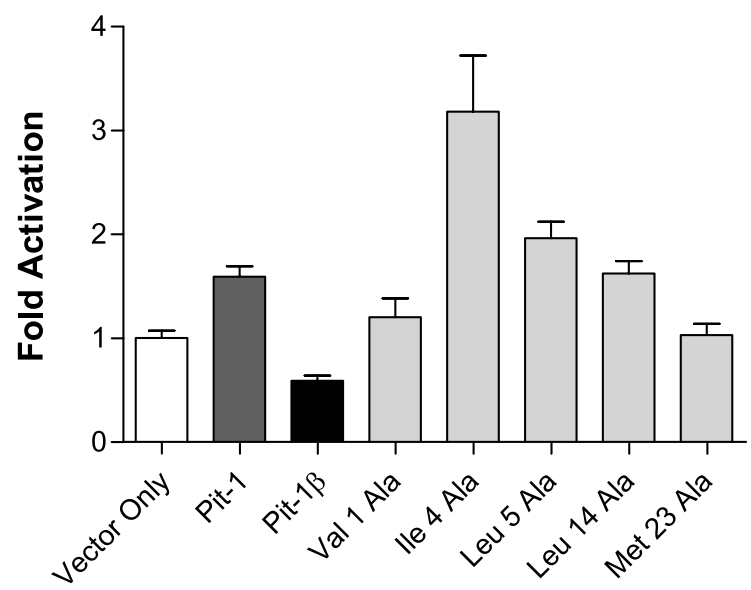

c.

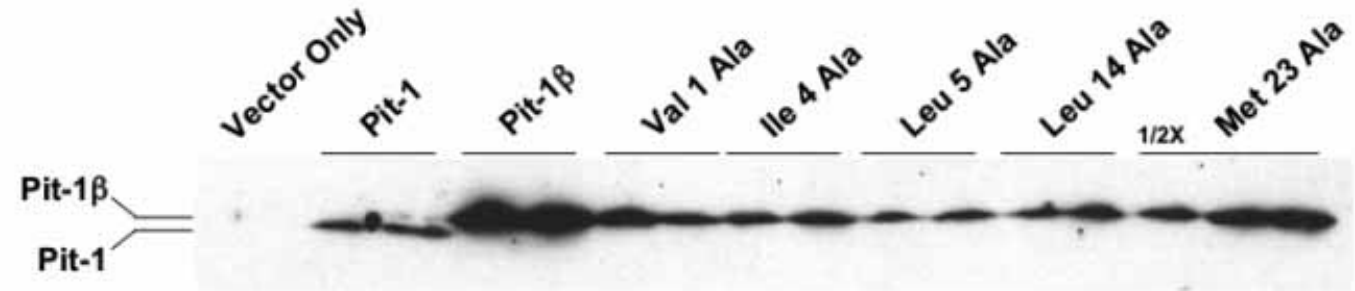

Figure 9 Hydrophobic residue to alanine mutations. Effects of Pit-1 $\beta$ constructs on activation of the rPRL promoter in non-pituitary HeLa cells (A) and GH3 pituitary cells (B). Plasmid pA3 PRL luc-425 (3 $\mu \mathrm{g})$, together with wild type or mutant pRSV HA Pit-1 $\beta$ $(30 \mu \mathrm{g})$, were introduced into GH3 pituitary cells by electroporation. Total RSV promoter amounts were maintained constant with pRSV $\beta$-globin DNA. After $24 \mathrm{~h}$, cells were harvested, and total light units were measured (See Materials and methods).

Expression levels of Pit-1 and Pit-1 $\beta$ (C). Plasmids pRSV HA Pit-1 $(10 \mu \mathrm{g})$, pRSV HA Pit-1 $\beta$ (30 $\mu \mathrm{g})$, and mutant pRSV HA Pit-1 $\beta$ $(30 \mu \mathrm{g})$ were introduced into GH3 pituitary cells by electroporation. After $24 \mathrm{~h}$ cells were harvested and analyzed by SDS PAGE and western blot (See Materials and methods).

than Threonine (Karplus 1997), and is found as often at solvent-exposed as at internal positions (Chothia 1976, Rose et al. 1985). Moreover, since there are no alanines in the $\beta$-domain (Fig. 1), each substitution is distinct from the endogenous sequence.

All of the alanine-substituted Pit-1 $\beta$ proteins retained basal transcriptional potency in isoform-insensitive HeLa non-pituitary cells, and activated the PRL promoter when compared with the vector only control (Fig. 9A). Pit-1 $\beta$ activated the PRL promoter 18-fold, and the five alanine-scanning mutants activated the promoter between 21- and 98-fold. In contrast to the sidechain-length and aliphatic vs aromatic mutations, the five alanine-substitution mutants activated the PRL promoter when compared with the vector only control even more than did wild type Pit-1 $\beta$.

In GH3 cells, the wild-type Pit- $1 \beta$ isoform reduced PRL promoter activity by $41 \%$ (Fig. 9B). Two of the alanine-substitution proteins, Val 1 Ala and Met 23 Ala, failed to reduce PRL promoter activity, and three of the alanine-substitution proteins actually increased PRL promoter activity between 2- and 3-fold. In our previous alanine-substitution mutagenesis studies, we also observed varying degrees of reversal of repression, from loss of repression to activation (Diamond \& GutierrezHartmann 2000).

The lack of effect of the Val 1 Ala and Met 23 Ala constructs on rPRL promoter activity in GH3 pituitary cells raised the concern that the mutant proteins may not be expressed, though their retention of transcription potency in HeLa non-pituitary cells argues against considerably altered protein expression. We performed western blot analysis of protein expression for these constructs in GH3 cells (Fig. 9G). The protein expression levels of the mutant constructs were roughly equivalent to that of wild-type Pit- $1 \beta$. We detected small differences 
in apparent mobility among the Pit-1 mutant constructs, likely due to sequence-specific effects on gel mobility of the mutant proteins, similar to those that we have seen previously with Pit-1 (Diamond \& Gutierrez-Hartmann 1996, 2000) and the poliovirus RNA polymerase (Diamond \& Kirkegaard 1994).

\section{Nonhydrophobic residues are not required for repression}

A further prediction of $\beta$-domain function solely through hydrophobicity would be that nonhydrophobic sidechains, unlike the hydrophobic sidechains, would be dispensable for repression. To test this hypothesis, we replaced nonhydrophobic $\beta$-domain amino acids with alanine. We chose five nonhydrophobic AAs (serine 6, glutamine 9, lysine 12, cysteine 13, and threonine 21) whose physical properties (Kawashima et al. 1999, Kawashima \& Kanehisa 2000) had been changed in previous mutageneses only by multiple AA substitution mutations that eliminated repression (Diamond \& Gutierrez-Hartmann 1996, 2000).

All of the alanine substitutions retained transcriptional potency in HeLa non-pituitary cells (Fig. 10A). Pit-1 $\beta$ activated the PRL promoter 7-fold compared with the vector-only control, and the five alanine-scanning mutants activated 2- to 10-fold. For three of the mutants (Ser 6 Ala, Cys 13 Ala and Thr 21 Ala) transcriptional potency was less than that of the wild-type Pit-1 $\beta$, and for two of the mutants (Gln $9 \mathrm{Ala}$ and Lys $12 \mathrm{Ala}$ ) transcriptional potency was greater than for that of the wild type.

In GH3 pituitary cells, the proteins with alaninesubstitutions for non-hydrophobic residues blocked PRL promoter activity between 60 and $83 \%$ compared with the vector only control, similar to the $65 \%$ repression by Pit-1 $\beta$ (Fig. 10B). These data demonstrate that the nonhydrophobic $\beta$-domain amino acids serine 6 , glutamine 9 , lysine 12, cysteine 13, and threonine 21 are not required for repression.

\section{Discussion}

Small repression domains can block transcription through diverse mechanisms, such as interference with host protein conformation (Necela \& Pollenz 1999). DNA binding (Katz et al. 1995, Roulet et al. 1995), recruitment of corepressors or other proteins (Zhang et al. 2002, Xia et al. 2003, Townson et al. 2004), or interference with positive interactions (Moffett et al. 1997). The ability of Pit- $1 \beta$ to bind DNA as well as Pit- 1 (Konzak \& Moore 1992, Sanchez-Pacheco et al. 1998) argues against a mechanism solely involving interference with DNA binding.
A.

\section{Activation in Pituitary (GH3) Cells Effect of non-Hydrophobic Residues}

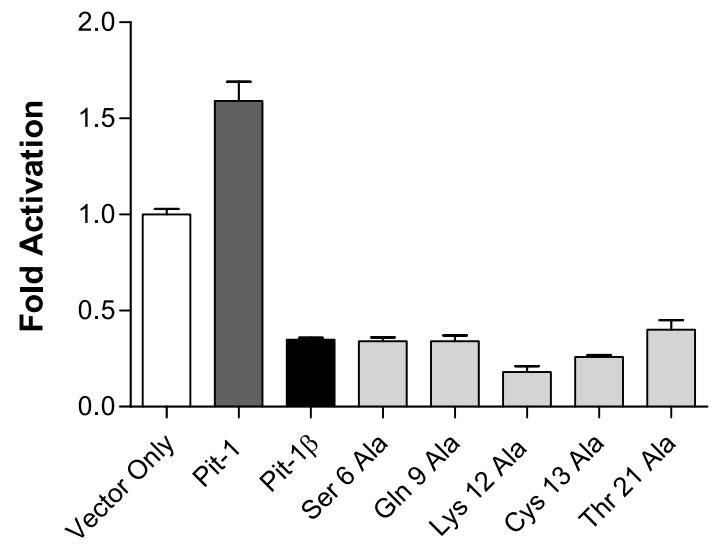

B.
Activation in non-Pituitary (HeLa) Cells Effect of non-Hydrophobic Residues

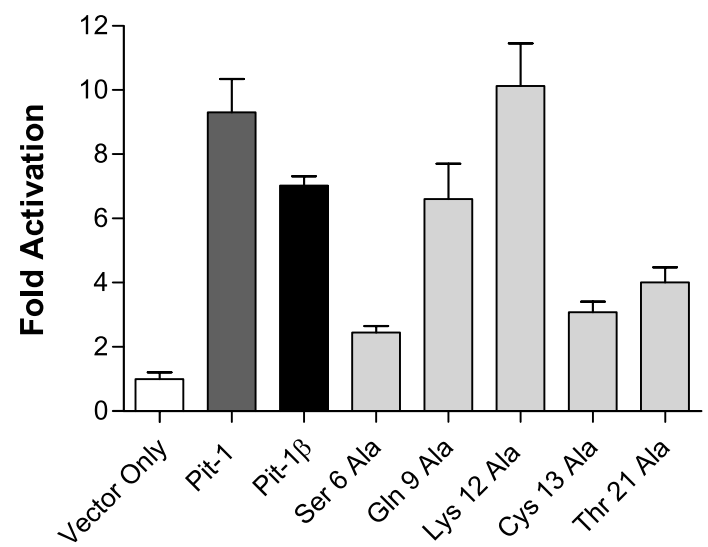

Figure10 Nonhydrophobic residue to Alanine mutations. Effects of Pit-1 $\beta$ constructs on activation of the rPRL promoter in non-pituitary HeLa cells (A) and GH3 pituitary cells (B). Plasmid pA3 PRL luc-425 $(3 \mu \mathrm{g})$, together with wild type or mutant pRSV HA Pit-1 $\beta(30 \mu \mathrm{g})$, were introduced into GH3 pituitary cells by electroporation. Total RSV promoter amounts were maintained constant with pRSV $\beta$-globin DNA. After $24 \mathrm{~h}$, cells were harvested, and total light units were measured (See Materials and methods).

The results of the reconstitution experiments (Figs 2-4) indicate that the decrease in CBP recruitment to the PRL promoter seen previously (Ferry et al. 2005) are due to interference by Pit- $1 \beta$ with the function of the Pit-1-CBP complex to transduce cAMP/PKA signaling. It has been shown that the POU domain of Pit-1 may interact with CBP through two cysteine-histidine rich domains (Xu et al. 1998, Zanger et al. 1999) and that POU factors can be modified by phosphorylation. For example, Pit-1 is phosphorylated in the POU domain 
(Thr-220). This phosphorylation results in decreased DNA binding to GH sites and increased DNA binding to TSH $\beta$ and PRL promoter sites. The failure of Pit-1 alone, CBP or even PKA alone seen previously (Diamond \& Gutierrez-Hartmann 1996, Diamond et al. 1999) to allow Pit-1 $\beta$ to reconstitute repression suggest that this repression is an emergent property of Pit-1 $\beta$ 's interaction with the Pit-1-CBP complex.

The correlation between the dosage of Pit- $1 \beta$ and the degree of activation of the PRL promoter by Pit-1, PKA and CBP (Figs 2-4) is typical of the dosage effects seen with dominant-negative poison products, which typically interact with one partner of a complex but fail to interact with others (Mains et al. 1990, Mounkes \& Fuller 1999). It has been shown that Pit-1 and non-liganded nuclear receptors (NR) can repress each other's signaling (Gonzalez \& Carlberg 2002). In this study, we propose a mechanism by which Pit- 1 interacts with Pit- $1 \beta$ resulting in cross-repression. This phenomenon may take place whenever Pit- 1 and Pit- $1 \beta$ are co-expressed. Our finding that the $\beta$-domain blocks physical interaction between Pit-1 and CBP AA 312-440 (Fig. 5) provides a physical basis for this model. Thus, the cell-type specificity of repression by Pit-1 $\beta$ would be due to the unique environment of anterior pituitary lactotroph and somatotrophs, which display tonic activation of the cAMP/PKA signaling cascade, and high levels of both Pit-1 and CBP.

The negative effect of the $\beta$-domain on both Ets-1 and Ras signaling transduction (Diamond \& GutierrezHartmann 1996) as well as the differential interaction of Pit-1 and Pit-1 $\beta$ with Ets-1 (Bradford et al. 2000) may also be a product of the insertion of the hydrophobic $\beta$-domain into the Pit-1 TAD. The $\beta$-domain insertionpoint lies at the boundary between the two TAD exons, R1 and R2, which regulate Pit-1-ETS-1 synergy and Ras response respectively (Duval $e$ t al. 2003). The lack of requirement for physical interaction between Ets-1 and Pit-1 for either Ras responsiveness or Pit-1-ETS-1 synergy suggests that the $\beta$-domain may interfere with coactivator recruitment by the Pit-1 and Ets-1 complex. Indeed, both Pit-1 and Ets-1 can interact with the AA 312-440 region of CBP.

The AA sequence requirements for $\beta$-domain repression are most consistent with a model of $\beta$-domain function solely through hydrophobicity. Current models of the function of transcriptional activator require specific charge and hydrophobic interactions to strengthen binding between conformationally flexible TADs and partner proteins (Hermann et al. 2001, De Guzman et al. 2004, Razeto et al. 2004, Zor et al. 2004). The lack of constraint for sidechain length (Fig. 6), sidechain chemistry (Fig. 7) or even AA order (Fig. 8) argues against the $\beta$-domain forming one side of a specific interface that involves surface complementarity. The requirement for only the $\beta$-domain's hydrophobic
(Figs 9 and 10) residues argues against a requirement for charge interactions, and suggests a threshold effect: the $\beta$-domain may be hydrophobic enough to block interaction between Pit-1 $\beta$ and CBP, but losses of hydrophilic properties do not increase the repression.

The effect of the $\beta$-domain mutations on transcription potency when expressed alone in HeLa cells correlates with their effect on repression in pituitary cells. This suggests that changes in $\beta$-domain sidechain structure have similar effects on both basal transcription potency in nonpituitary cells and the ability of Pit- $1 \beta$ to interact with CBP. The mechanism by which either Pit-1 or Pit- $1 \beta$ transduce PKA signaling in HeLa cells in the absence of $\mathrm{CBP}$ is clearly different from the mechanism in pituitary cells or in our current reconstitution experiments with $\mathrm{CBP}$, and underlines the importance of characterizing mutant transcription factors in their native environment.

How might the hydrophobic $\beta$-domain actually block interaction with and recruitment of CBP? The hydrophobicity of the $\beta$-domain is reminiscent of that of the hydrophobic rtARNTa repression domain (Necela \& Pollenz 1999), which can repress promoter activation by either ARNT or the yeast transcription factor Gal 4 through protein misfolding, possibly due to hydrophobic sidechain burial in the protein's interior. Similarly, the $\beta$-domain might alter the conformation of the Pit-1, perhaps directly affecting the POU-homeodomain, which has been shown to directly interact with CBP (Xu et al. 1998, Zanger et al. 1999). Alternatively, the $\beta$-domain might interfere with the conformational flexibility of the TAD, and prevent necessary interactions between Pit-1 and CBP. Two of CBP's zinc-finger domains in the AA 312-440 region form stable, well-ordered complexes with transcription factor TADs, which appear to involve the induced fit of an otherwise disordered TAD with a CBP zinc finger (Dial et al. 2003, Freedman et al. 2003).

Support for a model in which the $\beta$-domain alters the Pit-1 TAD to interfere with recruitment of CBP comes from the analysis of a mutation in Pit-1 that lead to familial combined pituitary hormone deficiency (CPHD), a genetic disorder of anterior pituitary function in which multiple anterior pituitary hormone genes are under-expressed. Twenty mutations in the Pit-1 locus have been identified that lead to CPHD ( $\mathrm{Li}$ et al. 1990, Ohta et al. 1992, Pfaffle et al. 1992, Radovick et al. 1992, Tatsumi et al. 1992, Gohen et al. 1995, 1999, Irie et al. 1995, Pellegrini-Bouiller et al. 1996, Brown et al. 1998, Fofanova et al. 1998, Pernasetti et al. 1998, 1999, Blankenstein et al. 2001, Hendriks-Stegeman et al. 2001, Vallette-Kasic et al. 2001). Of particular interest is a mutation that converts the conserved Proline at position 24 of the TAD to Leucine, and interferes with interaction between Pit-1 and CBP (Ohta et al. 1992, Cohen et al. 1996). Interestingly, the dominant-negative 
Pro 24 Leu Pit-1, like Pit-1 $\beta$, fails to block either PRL or GH promoter activity in non-pituitary cells and like Pit-1 $\beta$, actually activates those promoters (Kishimoto et al. 2002).

Future experiments will investigate the mechanism(s) that underlie the ability of the $\beta$-domain to block recruitment of CBP by Pit-1. Owing to its dominantnegative function with regard to the functional recruitment of CBP to the PRL promoter, Pit-1 $\beta$ also may provide a probe to identify additional downstream targets of Pit-1 and CBP.

\section{Acknowledgements}

The authors thank Ms Denise Sutton and Ms Cortney Stringer for technical assistance, and other members of the Diamond laboratory for their helpful suggestions and comments. We thank Drs Gutierrez-Hartmann, CheeGun Lee and Kate Horwitz for providing crucial reagents.

This work was supported by the American Cancer Society (RSG TBE-105036), the National Institutes of Health (NIDDK K01 DK02752 and NGRR P20 RR15592), and the Kentucky Research Challenge Trust Fund. The authors declare that there is no conflict of interest that would prejudice the impartiality of this scientific work.

\section{References}

Blankenstein O, Muhlenberg R, Kim C, Wuller S, Pfaffle R \& Heimann G 2001 A new c-terminal located mutation (v272 ter) in the Pit-1 gene manifesting with severe congenital hypothyroidism. Possible functionality of the Pit-1 c-terminus. Hormone Research $\mathbf{5 6}$ 81-86.

Bodner M \& Karin M 1987 A pituitary-specific trans-acting factor can stimulate transcription from the growth hormone promoter in extracts of nonexpressing cells. Cell $\mathbf{5 0} 267-275$.

Bradford AP, Conrad KE, Wasylyk C, Wasylyk B \& GutierrezHartmann A 1995 Functional interaction of c-ets-1 and ghf-1/Pit-1 mediates Ras activation of pituitary-specific gene expression: mapping of the essential c-ets-1 domain. Molecular and Cellular Biology 15 2849-2857.

Bradford A, Brodsky KS, Diamond S, Kuhn L, Liu Y \& GutierrezHartmann A 2000 The Pit-1 homeodomain and beta-domain interact with ets- 1 and modulate synergistic activation of the rat prolactin promoter. Foumal Biological Chemistry 275 3100-3106.

Bradford M 1976 A rapid and sensitive method for the quantitation of microgram quantities of protein utilizing the principle of protein-dye binding. Analytical Biochemistry 72 248-254.

Brown M, Parks J, Adess M, Rich B, Rosenthal I, Voss T, Vanderheyden TC \& Hurley DL 1998 Central hypothyroidism reveals compound heterozygous mutations in the Pit-1 gene. Hormone Research 49 98-102.

Camper SA, Yao YAS \& Rottman FM 1985 Hormonal regulation of the bovine prolactin promoter in rat pituitary tumor cells. Fournal of Biological Chemistry 260 12246-12251.

Chothia C 1976 The nature of the accessible and buried surfaces in proteins. Fournal of Molecular Biology 105 1-12.
Cohen L, Wondisford F, Salvatoni A, Maghnie M, Brucker-Davis F, Weintraub B \& Radovick S 1995 A "hot spot" in the Pit-1 gene responsible for combined pituitary hormone deficiency: clinical and molecular correlates. Fournal of Clinical Endocrinology and Metabolism 80 679-684.

Cohen L, Wondisford F \& Radovick S 1996 Role of Pit-1 in the gene expression of growth hormone, prolactin, and thyrotropin. Endocrinology and Metabolism Clinics of North America 25 523-540.

Cohen LE, Hashimoto Y, Zanger K, Wondisford F \& Radovick S 1999 Creb-independent regulation by CBP is a novel mechanism of human growth hormone gene expression. Fournal of Clinical Investigation 104 1123-1130.

Conrad KE \& Gutierrez-Hartmann A 1992 The Ras and protein kinase A pathways are mutually antagonistic in regulating rat prolactin promoter activity. Oncogene 7 1279-1286.

Day RN, Walder JA \& Maurer RA 1989 A protein kinase inhibitor gene reduces both basal and multihormone-stimulated prolactin gene transcription. Fournal of Biological Chemistry 264 431-436.

De Guzman RN, Martinez-Yamout MA, Dyson H \& Wright P 2004 Interaction of the TAZ1 domain of the CREB-binding protein with the activation domain of CITED2: regulation by competition between intrinsically unstructured ligands for non-identical binding sites. Fournal of Biological Chemistry $\mathbf{2 7 9}$ 3042-3049.

Deardorff J \& Sachs A 1997 Differential effects of aromatic and charged residue substitutions in the RNA binding domains of the yeast poly(A)-binding protein. Fournal of Molecular Biology $\mathbf{2 6 9}$ 67-81.

Dial R, Sun Z \& Freedman S 2003 Three conformational states of the p300 $\mathrm{CH} 1$ domain define its functional properties. Biochemistry 42 9937-9945.

Diamond S \& Gutierrez-Hartmann A 1996 A 26-amino acid insertion domain defines a functional transcription switch motif in Pit-1 beta. Fournal of Biological Chemistry 271 28925-28932.

Diamond SE \& Gutierrez-Hartmann A 2000 The Pit-1 beta domain dictates active repression and alteration of histone acetylation of the proximal prolactin promoter. Fournal of Biological Chemistry 275 30977-30986.

Diamond S \& Kirkegaard K 1994 Clustered charged-to-alanine mutagenesis of poliovirus RNA-dependent RNA polymerase yields multiple temperature-sensitive mutants defective in RNA synthesis. Fournal of Virology 68 863-876.

Diamond SE, Chiono M \& Gutierrez-Hartmann A 1999 Reconstitution of the protein kinase A response of the rat prolactin promoter: differential effects of distinct Pit-1 isoforms and functional interaction with Oct-1. Molecular Endocrinology 13 228-238.

Duval D, Jean A \& Gutierrez-Hartmann A 2003 Ras signaling and transcriptional synergy at a flexible ets-1/Pit-1 composite DNA element is defined by the assembly of selective activation domains. Fournal of Biological Chemistry 278 39684-39696.

Elsholtz H, Albert V, Treacy M \& Rosenfeld M 1990 A two-base change in a POU factor-binding site switches pituitary-specific to lymphoid-specific gene expression. Genes and Development 4 43-51.

Elsholtz HP, Lew AM, Albert PR \& Sundmark VC 1991 Inhibitory control of prolactin and Pit-1 gene promoters by dopamine. Fournal of Biological Chemistry 266 22919-22925.

Ferry A, Jonsen M, Locasto DM, Brodsky K, Gutierrez-Hartmann A \& Diamond SE 2005 Pit-1 beta blocks transcription in a DNA context-dependent manner. Fournal of Endocrinology 185 173-185.

Fofanova O, Takamura N, Kinoshita E, Yoshimoto M, Tsuji Y, Peterkova V, Evgrafov O, Dedov I, Goncharov N \& Yamashita S 1998 Rarity of Pitl involvement in children from russia with combined pituitary hormone deficiency. American Fournal of Medical Genetics 77 360-365.

Freedman S, Sun Z, Kung A, France D, Wagner G \& Eck M 2003 Structural basis for negative regulation of hypoxia-inducible factor-1 alpha by CITED2. Nature Structural Biology 10 504-512. 
Gonzalez M \& Carlberg C 2002 Cross-repression, a functional consequence of the physical interaction of non-liganded nuclear receptors and POU domain transcription factors. Fournal Biological Chemistry 277 18501-18509.

Gutierrez-Hartmann A, Siddiqui S \& Loukin S 1987 Selective transcription and DNase I protection of the rat prolactin gene by GH3 pituitary cell-free extracts. PNAS 84 5211-5215.

Hashimoto K, Zanger K, Hollenberg A, Cohen L, Radovick S \& Wondisford F 2000 Camp response element-binding proteinbinding protein mediates thyrotropin-releasing hormone signaling on thyrotropin subunit genes. Fournal of Biological Chemistry $\mathbf{2 7 5}$ 33365-33372.

Hendriks-Stegeman BI, Augustijn K, Bakker B, Holthuizen P, van der Vliet PC \& Jansen M 2001 Combined pituitary hormone deficiency caused by compound heterozygosity for two novel mutations in the POU domain of the Pit1/POU1F1 gene. Fournal of Clinical Endocrinology and Metabolism 86 1545-1550.

Hermann S, Berndt K \& Wright A 2001 How transcriptional activators bind target proteins. Fournal of Biological Chemistry $\mathbf{2 7 6}$ 40127-40132.

Herr W, Sturm RA, Clerc RG, Corcoran LM, Baltimore D, Sharp PA, Ingraham HA, Rosenfeld MG, Finney M, Ruvkun G \& Horvitz HR 1988 The POU domain: a large conserved region in the mammalian pit-1, oct-1, oct-2, and caenorhabditis elegans unc-86 gene products. Genes and Development 2 1513-1516.

Heyl D, Schmitter S, Bouzit H, Johnson T, Hepp A, Kurtz K \& Mousigian C 1994 Substitution of aromatic and nonaromatic amino acids for the Phe3 residue in the delta-selective opioid peptide deltorphin I: effects on binding affinity and selectivity. International Fournal of Peptides and Protein Research 44 420-426.

Ingraham HA, Chen RP, Mangalam HJ, Elsholtz HP, Flynn SE, Lin CR, Simmons DM, Swanson L \& Rosenfeld MG 1988 A tissue-specific transcription factor containing a homeodomain specifies a pituitary phenotype. Cell $\mathbf{5 5}$ 519-529.

Ingraham HA, Flynn SE, Voss JW, Albert VR, Kapiloff MS, Wilson L \& Rosenfeld MG 1990 The POU-specific domain of Pit-1 is essential for sequence-specific, high affinity DNA binding and DNA-dependent Pit-1-Pit-1 interactions. Cell 61 1021-1033.

Irie Y, Tatsumi K, Kusuda S, Kawawaki H, Boyages SC, Nose O, Ichiba Y, Katsumata N \& Amino N 1995 Screening for PIT1 abnormality by PCR direct sequencing method. Thyroid $\mathbf{5}$ 207-211.

Iverson R, Day K, D'emden M, Day R \& Maurer R 1990 Clustered point mutation analysis of the rat prolactin promoter. Molecular Endocrinology 4 1564-1571.

Kapiloff MS, Farkash Y, Wegner M \& Rosenfeld MG 1991 Variable effects of phosphorylation of Pit-1 dictated by the DNA response elements. Science 253 786-789.

Karplus P 1997 Hydrophobicity regained. Protein Science 6 1302-1307.

Katz D, Reginato M \& Lazar M 1995 Functional regulation of thyroid hormone receptor variant TR alpha 2 by phosphorylation. Molecular and Cellular Biology 15 2341-2348.

Kawashima S \& Kanehisa M 2000 AAindex: amino acid index database. Nucleic Acids Research 28374

Kawashima S, Ogata H \& Kanehisa M 1999 AAindex: amino acid index database. Nucleic Acids Research 27 368-369.

Keech CA \& Gutierrez-Hartmann A 1989 Analysis of rat prolactin promoter sequences that mediate pituitary-specific and $3^{\prime}, 5^{\prime}$-cyclic adenosine monophosphate-regulated gene expression in vivo. Molecular Endocrinology 3 832-839.

Keech C, Jackson S, Siddiqui S, Ocran K \& Gutierrez-Hartmann A 1992 Cyclic adenosine $3^{\prime}, 5^{\prime}$-monophosphate activation of the rat prolactin promoter is restricted to the pituitary-specific cell type. Molecular Endocrinology 6 2059-2070.

Kievit P \& Maurer R 2005 The pituitary-specific transcription factor, Pit-1, can direct changes in the chromatin structure of the prolactin promoter. Molecular Endocrinology 19 138-147.
Kishimoto M, Okimura Y, Yagita K, Iguchi G, Fumoto M, Iida K, Kaji H, Okamura H \& Chihara K 2002 Novel function of the transactivation domain of a pituitary-specific transcription factor, Pit-1. Fournal of Biological Chemistry 277 45141-45148.

Klapper M 1977 The independent distribution of amino acid near neighbor pairs into polypeptides. Biochemical and Biophysical Research Communications 78 1018-1024.

Konzak KE \& Moore DD 1992 Functional isoforms of Pit-1 generated by alternative mRNA splicing. Molecular Endocrinology 6 241-247.

Lacerte A, Lee E, Reynaud R, Canaff L, De Guise C, Devost D, Ali S, Hendy G \& Lebrun JJ 2004 Activin inhibits pituitary prolactin expression and cell growth through SMADs, Pit-1 and menin. Molecular Endocrinology 18 1558-1569.

Lai J \& Herr W 1992 Ethidium bromide provides a simple tool for identifying genuine DNA-independent protein associations. PNAS 89 6958-6962.

Lew A \& Elsholtz H 1995 A dopamine-responsive domain in the N-terminal sequence of Pit-1. Transcriptional inhibition in endocrine cell types. Fournal of Biological Chemistry $\mathbf{2 7 0}$ 7156-7160.

Li S, Crenshaw EB III, Rawson E, Simmons DM, Swanson LW \& Rosenfeld M 1990 Dwarf locus mutants lacking three pituitary cell types result from mutations in the POU-domain gene pit-1. Nature 347 528-533.

Mains P, Sulston I \& Wood W 1990 Dominant maternal-effect mutations causing embryonic lethality in caenorhabditis elegans. Genetics 125 351-369.

Maurer RA 1981 Transcriptional regulation of the prolactin gene by ergocryptine and cyclic AMP. Nature 294 94-97.

Moffett P, Reece M \& Pelletier J 1997 The murine Sim-2 gene product inhibits transcription by active repression and functional interference. Molecular and Cellular Biology 17 4933-4947.

Morris AE, Kloss B, Mcchesney R, Bancroft C \& Chasin LA 1992 An alternatively spliced Pit-1 isoform altered in its ability to trans-activate. Nucleic Acids Research 20 1355-1361.

Mounkes LC \& Fuller M 1999 Molecular characterization of mutant alleles of the DNA repair/basal transcription factor haywire/ERCC3 in Drosophila. Genetics 152 291-297.

Murray MB, Tadaki DK, Campion SR, Lamerdin JA, Serpersu EH, Bradrick TD \& Niyogi SK 1998 Structure-function analysis of a conserved aromatic cluster in the N-terminal domain of human epidermal growth factor. Protein Engineering 11 1041-1050.

Nakagawa S, Tager H \& Steiner D 2000 Mutational analysis of invariant valine B12 in insulin: implications for receptor binding. Biochemistry 39 15826-15835.

Necela B \& Pollenz R 1999 Functional analysis of activation and repression domains of the rainbow trout aryl hydrocarbon receptor nuclear translocator (rtARNT) protein isoforms. Biochemical Pharmacology 57 1177-1190.

Ohta K, Nobukuni Y, Mitsubuchi H, Fujimoto S, Matsuo N, Inagaki H, Endo F \& Matsuda I 1992 Mutations in the Pit-1 gene in children with combined pituitary hormone deficiency. Biochemical and Biophysical Research Communications 189 851-855.

Parks J, Brown M, Hurley D, Phelps C \& Wajnrajch M 1999 Heritable disorders of pituitary development. Fournal of Clinical Endocrinology and Metabolism 84 4362-4370.

Pellegrini-Bouiller I, Belicar P, Barlier A, Gunz G, Charvet JP, Jaquet P, Brue T, Vialettes B \& Enjalbert A 1996 A new mutation of the gene encoding the transcription factor Pit-1 is responsible for combined pituitary hormone deficiency. Fournal of Clinical Endocrinology and Metabolism 81 2790-2796.

Pernasetti F, Milner R, Al AAA, De ZF, Chavez V, Muller M \& Martial J 1998 Pro239 Ser: a novel recessive mutation of the Pit-1 gene in seven middle eastern children with growth hormone, prolactin, and thyrotropin deficiency. Fournal of Clinical Endocrinology and Metabolism 83 2079-2083. 
Pfaffle R, Dimattia G, Parks J, Brown M, Wit J, Jansen M, Van DNH, Van DBJL, Rosenfeld M \& Ingraham H 1992 Mutation of the POU-specific domain of Pit-1 and hypopituitarism without pituitary hypoplasia. Science $2571118-1121$.

Pfaffle R, Blankenstein O, Wuller S \& Kentrup H 1999 Combined pituitary hormone deficiency: role of Pit-1 and prop-1. Acta Paediatrica Supplement $\mathbf{8 8} 33-41$.

Pickett CA \& Gutierrez-Hartmann A 1997. Molecular and cellular ontogeny of distinct pituitary cell types. In Pituitary Disease: Diagnosis and Treatment, Chapter 2 pp 1-31. Ed. Wierman ME. Totowa, NY: Humana Press, Inc.

Radovick S, Nations M, Du Y, Berg L, Weintraub B \& Wondisford F 1992 A mutation in the POU-homeodomain of Pit-1 responsible for combined pituitary hormone deficiency. Science $\mathbf{2 5 7}$ 1115-1118.

Razeto A, Ramakrishnan V, Litterst C, Giller K, Griesinger C, Carlomagno T, Lakomek N, Heimburg T, Lodrini M, Pfitzner E \& Becker S 2004 Structure of the NCoA-1/SRC-1 PAS-B domain bound to the LXXLL motif of the STAT6 transactivation domain. Fournal of Molecular Biology 336 319-329.

Rose G, Geselowitz A, Lesser GJ, Lee R \& Zehfus M 1985 Hydrophobicity of amino acid residues in globular proteins. Science $229834-838$.

Roulet E, Armentero M, Krey G, Corthesy B, Dreyer C, Mermod N \& Wahli W 1995 Regulation of the DNA-binding and transcriptional activities of Xenopus Laevis NFI-X by a novel G-terminal domain. Molecular and Cellular Biology 15 5552-5562.

Sanchez-Pacheco A, Pena P, Palomino T, Guell A, Castrillo JL \& Aranda A 1998 The transcription factor GHF-1, but not the splice variant GHF-2, cooperates with thyroid hormone and retinoic acid receptors to stimulate rat growth hormone gene expression. FEBS Letters 422 103-107.

Sanyal S \& Van Tol HH 1997 Dopamine D4 receptor-mediated inhibition of cyclic adenosine $3^{\prime}, 5^{\prime}$-monophosphate production does not affect prolactin regulation. Endocrinology 138 1871-1878.

Scully KM, Jacobson EM, Jepsen K, Lunyak V, Viadiu H, Carriere C, Rose DW, Hooshmand F, Aggarwal AK \& Rosenfeld MG 2000 Allosteric effects of Pit-1 DNA sites on long-term repression in cell type specification. Science 290 1127-1131.

Segil N, Roberts S \& Heintz N 1991 Mitotic phosphorylation of the oct-1 homeodomain and regulation of oct-1 DNA binding activity. Science 254 1814-1816.

Tashjian AHJ, Yasumura Y, Levine L, Sato GH \& Parker ML 1968 Establishment of clonal strains of rat pituitary tumor cells that secrete growth hormone. Endocrinology 82 342-352.

Tatsumi K, Miyai K, Notomi T, Kaibe K, Amino N, Mizuno Y \& Kohno H 1992 Cretinism with combined hormone deficiency caused by a mutation in the pitl gene. Nature Genetics 1 56-58.

Theill LE, Castrillo JL, Wu D \& Karin M 1989 Dissection of functional domains of the pituitary-specific transcription factor GHF-1. Nature 342 945-948.

Theill LE, Hattori K, Domenico D, Castrillo JL \& Karin M 1992 Differential splicing of the GHFl primary transcript gives rise to two functionally distinct homeodomain proteins. European Molecular Biology Organization fournal 11 2261-2269.
Tolon RM, Castillo AI \& Aranda A 1998 Activation of the prolactin gene by peroxisome proliferator-activated receptor-alpha appears to be DNA binding-independent. Fournal of Biological Chemistry 273 26652-26661.

Townson S, Kang K, Lee A \& Oesterreich S 2004 Structurefunction analysis of the estrogen receptor alpha corepressor scaffold attachment factor-B 1: identification of a potent transcriptional repression domain. Fournal of Biological Chemistry 279 26074-26081.

Vallette-Kasic S, Pellegrini-Bouiller I, Sampieri F, Gunz G, Diaz A, Radovick S, Enjalbert A \& Brue T 2001 Combined pituitary hormone deficiency due to the F135C human Pit-1 (pituitaryspecific factor 1) gene mutation: functional and structural correlates. Molecular Endocrinology 15 411-420.

Voss JW, Wilson L \& Rosenfeld MG 1991 POU-domain proteins Pit-1 and oct-1 interact to form a heteromeric complex and can cooperate to induce expression of the prolactin promoter. Genes and Development 5 1309-1320.

Voss JW, Wilson L, Rhodes SJ \& Rosenfeld MG 1993 An alternative Pit-1 RNA splicing product reveals modular binding and nonmodular transcriptional activities of the POU-specific domain. Molecular Endocrinology 7 1551-1560.

Vu C, Robblee J, Werner K \& Fairman R 2001 Effects of charged amino acids at $\mathrm{b}$ and $\mathrm{c}$ heptad positions on specificity and stability of four-chain coiled coils. Protein Science 10 631-637.

Wertman KF, Drubin DG \& Botstein D 1992 Systematic mutational analysis of the yeast actl gene. Genetics 132 337-350.

Xia Z, Anderson M, Diaz M \& Zeleznik-Le NJ 2003 MLL repression domain interacts with histone deacetylases, the polycomb group proteins HPC2 and BMI-1, and the corepressor C-terminal-binding protein. PNAS $1008342-8347$.

Xu L, Lavinsky RM, Dasen JS, Flynn SE, Mcinerney EM, Mullen TM, Heinzel T, Szeto D, Korzus E, Kurokawa R, Aggarwal AK, Rose DW, Glass CK \& Rosenfeld MG 1998 Signal-specific co-activator domain requirements for Pit-1 activation. Nature 395 301-306.

Zanger K, Cohen LE, Hashimoto K, Radovick S \& Wondisford FE 1999 A novel mechanism for cyclic adenosine $3^{\prime}, 5^{\prime}$-monophosphate regulation of gene expression by CREB-binding protein. Molecular Endocrinology 13 268-275.

Zanger K, Radovick S \& Wondisford F 2001 CREB binding protein recruitment to the transcription complex requires growth factor-dependent phosphorylation of its GF box. Molecular Cell 7 $551-558$.

Zhang Z, Varanasi U \& Trumbly R 2002 Functional dissection of the global repressor Tupl in yeast: dominant role of the C-terminal repression domain. Genetics 161 957-969.

Zor T, De Guzman RN, Dyson H \& Wright P 2004 Solution structure of the KIX domain of CBP bound to the transactivation domain of c-Myb. Fournal of Molecular Biology 337 521-534.

Received 24 June 2005

Accepted 19 July 2005 